\title{
EFEK EKSTRAK KACANG TUNGGAK (Vigna unguiculata) TERHADAP KADAR SUPEROKSIDA DISMUTASE (SOD) SERUM TIKUS GALUR WISTAR (Rattus norvegicus) YANG DIPAPAR DENGAN ASAP MESIN BERBAHAN BAKAR BENSIN
}

\author{
Arum Gladys Kusumaningrum*, Bambang Prijadi* ${ }^{* \bowtie}$, Moch. Aris Widodo***
}

\begin{abstract}
Abstrak
Emisi kendaraan bermotor mengandung komponen particulate matter (PM) yang memiliki efek proinflamasi melalui pembentukan reactive oxygen species (ROS). Peningkatan ROS akan berdampak pada stres oksidatif yang menyebabkan penurunan kadar antioksidan. Kacang tunggak mengandung senyawa genistein yang dapat bekerja sebagai antioksidan sehingga mampu mencegah terjadinya stres oksidatif akibat paparan asap. Tujuan penelitian ini adalah untuk menentukan pengaruh pemberian ekstrak kacang tunggak terhadap kadar SOD serum pada tikus Wistar. Studi eksperimental ini menggunakan post test only control group design. Sebanyak tiga puluh enam tikus Wistar jantan dibagi secara acak dalam 9 kelompok, terdiri dari kelompok kontrol negatif $(\mathrm{N})$, kelompok yang diberi oksigen 4 menit $\left(\mathrm{N}+\mathrm{O}_{4}\right)$, kelompok yang diberi ekstrak kacang tunggak $(\mathrm{N}+\mathrm{G})$, kelompok yang diberi perlakuan asap 2, 3 dan 4 menit, masing-masing diberikan oksigen 4 menit tanpa ekstrak kacang tunggak $\left(\mathrm{A}_{2} \mathrm{O}_{4}(-) \mathrm{G}, \mathrm{A}_{3} \mathrm{O}_{4}(-) \mathrm{G}, \mathrm{A}_{4} \mathrm{O}_{4}(-) \mathrm{G}\right)$ dan dengan ekstrak kacang tunggak $\left(\mathrm{A}_{2} \mathrm{O}_{4}(+) \mathrm{G}, \mathrm{A}_{3} \mathrm{O}_{4}(+) \mathrm{G}, \mathrm{A}_{4} \mathrm{O}_{4}(+) \mathrm{G}\right)$. Pemaparan asap dilakukan setiap hari selama 30 hari. Variabel yang diukur pada penelitian ini adalah kadar SOD serum. Hasil uji ANOVA menunjukkan adanya perbedaan antar kelompok yang signifikan $(p<0,05)$. Hasil analisis statistik post hoc $L S D$ menunjukkan bahwa kadar SOD serum kelompok tikus $\mathrm{A}_{2} \mathrm{O}_{4}(+) G, \mathrm{~A}_{3} \mathrm{O}_{4}(+) \mathrm{G}, \mathrm{A}_{4} \mathrm{O}_{4}(+) \mathrm{G}$ meningkat signifikan dibandingkan dengan kelompok tikus $\mathrm{A}_{2} \mathrm{O}_{4}(-) \mathrm{G}, \mathrm{A}_{3} \mathrm{O}_{4}(-) \mathrm{G}, \mathrm{A}_{4} \mathrm{O}_{4}(-) \mathrm{G}$. Kesimpulan dari penelitian ini adalah ekstrak kacang tunggak dapat mencegah penurunan kadar SOD serum tikus wistar yang dipapar asap mesin berbahan bakar bensin
\end{abstract}

Kata Kunci: asap mesin berbahan bakar bensin, kacang tunggak, particulate matter (PM), superoksida dismutase.

\section{THE EFFECT OF COWPEA (Vigna unguiculata) EXTRACT ON SUPEROXIDE DISMUTASE (SOD) SERUM OF WISTAR RATS (Rattus norvegicus) EXPOSED TO PETROL-FUELED ENGINE EXHAUST}

\begin{abstract}
Petrol-fueled engine exhaust consisting of particulate matter exerts pro-inflammatory effects through the generation of reactive oxygen species (ROS). Excessive generation of ROS leads to oxidative stress causing antioxidant level to decrease. Cowpea contains genistein as an antioxidant, prevent oxidative stress after being exposed to petrol-fueled engine exhaust. The purpose of this study was to determine the effect of cowpea extract on SOD serum in Wistar rat after being exposed to petrol-fueled engine exhaust. This study use post test only control group design. Thirty six male wistar rats were randomly selected and divided into nine groups, consisted of control negative group $(\mathrm{N})$, normal + oxygen $\left(\mathrm{N}+\mathrm{O}_{4}\right)$, normal + cowpea extract $(\mathrm{N}+\mathrm{G})$, wistar rat with 2, 3, and 4 minutes exposure + oxygen without cowpea extract (A2O4(-)G, A3O4(-)G, $\mathrm{A} 4 \mathrm{O} 4(-) \mathrm{G})$ and with cowpea extract (A2O4(+)G, A3O4(+)G, A4O4(+)G). Intervention was given each day for thirty days. The measured variable was SOD serum. ANOVA test showed a significant difference between all groups $(p<0.05)$. The post hoc LSD test showed significant increase of SOD serum in A2O4(+)G, A3O4(+)G, A4O4(+)G compared to A2O4(-)G, A304(-)G, A404(-)G. The conclusion was cowpea prevent the decreasing of SOD serum level in Wistar rat exposed to petrol-fueled engine exhaust.
\end{abstract}

Keywords: cowpea, particulate matter (PM), petrol-fueled engine exhaust, superoxide dismutase.

* Program Studi Pendidikan Dokter, FKUB

** Lab Biokimia dan Biomolekuler, FKUB

*** Lab Farmakologi, FKUB

bambang.prijadi@yahoo.com 


\section{Pendahuluan}

Hingga 2010 lalu jumlah kendaraan bermotor di dunia telah mencapai 1,015 miliar unit. Peningkatan jumlah kendaraan bermotor juga terjadi di Indonesia. Data dari Gabungan Industri Kendaraan Bermotor Indonesia (Gaikindo) dan Asosiasi Industri Sepeda Motor Indonesia (AISI) menunjukkan bahwa jumlah kendaraan bermotor di Indonesia hingga 2010 lalu mencapai 50.824.128 unit, dimana rasio antara jumlah penduduk dengan kendaraan bermotor di Indonesia 1:4,6. Bahkan jumlah kendaraan di Indonesia menempati urutan pertama di kawasan Asia Tenggara karena pada saat yang sama jumlah kendaraan di negara ASEAN lainnya di bawah 26 juta unit. Diperkirakan jumlah kendaraan di Indonesia dalam beberapa tahun terakhir akan terus bertambah 10-15 persen. ${ }^{1}$

Emisi kendaraan bermotor mengandung senyawa kompleks yang terdiri dari fase gas dan partikulat. Fase gas mengandung bahan iritan dan noniritan seperti NOx, SOx, dan COx serta hidrokarbon seperti senyawa alkohol, aldehid, dan derivat keton. Fase partikulat atau diesel exhaust particle (DEP) merupakan particulate matter (PM), berukuran sangat kecil dan mudah terhirup. ${ }^{2}$

Sumber utama PM meliputi proses kombusi, mekanis, dan debu environmental. PM dikategorikan secara luas menurut diameter aerodinamisnya yaitu fine particle $(<2,5 \mu \mathrm{m}$ [PM2.5]) dan ultrafine $(<0,1 \mu \mathrm{m}$ [UFP], yang kebanyakan berasal dari gas diesel serta coarse particle (2,5 sampai $10 \mu \mathrm{m}[\mathrm{PM} 10-2,5])$, yang berasal dari proses penghancuran dan pengasahan suatu permukaan benda. ${ }^{3}$

Mekanisme PM dalam menimbulkan dampak terhadap kesehatan adalah menginduksi efek proinflamasi sel target, seperti sel endothel, makrofag, dan sel epitel melalui pembentukan reactive oxygen species (ROS) dan stres oksidatif. Efek prooksidatif ini dipicu oleh molekul-molekul organik siklus redoks dan metal transisi yang terdapat pada permukaan partikel. ${ }^{4}$ $\begin{array}{lll}\text { Superoksida } & \text { dismutase } & \text { (SOD) } \\ \text { merupakan suatu antioksidan } & \text { yang }\end{array}$ mendismutase ROS seperti superoksida $\left(\mathrm{O}_{2}\right)$ yang reaktif menjadi $\mathrm{O}_{2}$ dan $\mathrm{H}_{2} \mathrm{O}_{2}$. SOD melindungi sel terhadap gangguan oksidan (radikal bebas) dan juga memelihara keseimbangan beberapa oksigen yang toksik. $^{5}$

Reactive oxygen species (ROS) seperti superoksida menginduksi terjadinya stres oksidatif. Stres oksidatif merupakan suatu keadaan dengan tingkat ROS yang toksik melebihi pertahanan antioksidan endogen. ${ }^{6}$

Kacang tunggak mengandung genistein, yaitu golongan isoflavone fitoestrogen yang selain mempunyai efek estrogenik juga mempunyai efek antioksidan. Potensi antioksidatif genistein dapat melindungi terjadinya stres oksidatif. ${ }^{7}$ Genistein yang terkandung dalam kacang tunggak dapat menurunkan kadar lipid peroksidase dan meningkatkan kadar SOD. ${ }^{8}$

Melihat potensi genistein pada ekstrak kacang tunggak berperan sebagai antioksidan dalam menurunkan stres oksidatif perlu dilakukan pembuktian tentang efek ekstrak kacang tunggak terhadap kadar SOD serum tikus Wistar yang dipapar asap mesin berbahan bakar bensin.

\section{Bahan dan Metode}

\section{Desain Penelitian}

Penelitian ini menggunakan metode true experimental design dengan post test only control group design. Sampel dipilih secara acak dan kemudian dibagi dalam sembilan kelompok yang masing-masing terdiri dari 4 hewan coba, yaitu kelompok kontrol negatif $(\mathrm{N})$, kelompok yang diberi oksigen 4 menit $\left(\mathrm{N}+\mathrm{O}_{4}\right)$, kelompok yang diberi ekstrak kacang tunggak $(\mathrm{N}+\mathrm{G})$, kelompok yang diberi perlakuan asap 2, 3 dan 4 menit, masing-masing diberikan oksigen 4 menit dengan ekstrak kacang tunggak $\left(\mathrm{A}_{2} \mathrm{O}_{4}(+) \mathrm{G}\right.$, $\left.\mathrm{A}_{3} \mathrm{O}_{4}(+) \mathrm{G}, \quad \mathrm{A}_{4} \mathrm{O}_{4}(+) \mathrm{G}\right)$ dan tanpa ekstrak kacang tunggak $\left(\mathrm{A}_{2} \mathrm{O}_{4}(-) \mathrm{G}, \mathrm{A}_{3} \mathrm{O}_{4}(-) \mathrm{G}\right.$, $\left.\mathrm{A}_{4} \mathrm{O}_{4}(-) \mathrm{G}\right)$. Variabel tergantung pada penelitian ini adalah kadar SOD serum. Proses adaptasi hewan coba dilakukan 
selama 7 hari dilanjutkan dengan perlakuan selama 30 hari.

\section{Ekstraksi Kacang tunggak}

Kacang tunggak yang digunakan adalah KT-6 tersertifikasi dari BALITKABI Malang. Kacang tunggak dikering-anginkan dan digiling hingga halus. Sebanyak $100 \mathrm{~g}$ serbuk kering kacang tunggak dimaserasi dengan metanol 95\% untuk mendapatkan bahan aktifnya, yaitu genistein. Selanjutnya etanol yang mengandung bahan aktif dievaporasi menggunakan rotary evaporator hingga didapatkan substrat berbentuk pasta yang merupakan hasil ekstraksi. Kandungan genistein diukur menggunakan LC-MS.

\section{Perlakuan Asap dan Pemberian Ekstrak Kacang Tunggak}

Tikus dimasukkan dalam kandang yang ditutup anyaman kawat berongga-rongga. Tiap kandang berisi 3 tikus. Kandang diletakkan pada suhu ruang $20-25{ }^{\circ} \mathrm{C}$. Sebelum perlakuan, tikus diadaptasikan dulu dengan kondisi laboratorium selama 1 minggu agar tidak stres. Alas sekam pada kandang diganti 2 kali setiap minggu. Pengukuran berat badan tikus dilakukan 1 kali minggu. Tikus diberi pakan standar Comfeed PARS 40 g/ekor. Minum tikus diletakkan pada botol minum dengan kebutuhan harian $60 \mathrm{ml} / \mathrm{ekor}$. Pemaparan dilakukan setiap hari pada pagi dan sore. Ekstrak kacang tunggak diberikan 30 menit sebelum pemaparan melalui alat sonde dengan dosis $0,5 \mathrm{mg} / \mathrm{kgBB} / \mathrm{hari}$. Setelah 30 hari tikus dibedah kemudian diambil sampel darah dari jantung untuk diambil serum kemudian dilakukan penghitungan kadar SOD serum dengan spektrofotometer.

\section{Pengukuran Kadar Superoksida Dismutase (SOD) Serum}

Prinsip pemeriksaan kadar SOD adalah sebagai berikut. Reaksi antara xanthine dan xanthine oxidase menghasilkan radikal superoksida. Radikal superoksida akan mereduksi nitroblue tetrazolium (NBT) menjadi formazan berwarna ungu. SOD dapat menghambat reduksi NBT melalui reaksinya dengan radikal superoksida yang menghasilkan $\mathrm{O}_{2}$ dan $\mathrm{H}_{2} \mathrm{O}$. Pengukuran dilakukan dengan metode kolorimetri menggunakan spektrofotometer. Pengukuran kadar SOD dilakukan secara tidak langsung, karena yang diukur dengan spektrofotometer adalah absorbansi formazan. Kemudian ditentukan konsentrasi SOD dengan menggunakan kurva standar SOD.

\section{Analisis Data}

Hasil penghitungan jumlah sel endotel dan pengukuran ketebalan dinding arteri koroner dianalisis secara statistik dengan program SPSS 16.0. for Windows. Uji statistik dilakukan pada derajat kepercayaan 95\% $(\alpha=0,05)$ dengan tingkat signifikansi $p$ $<0,05$. Analisis data menggunakan uji statistic one-way ANOVA, uji post hoc LSD.

\section{Hasil}

\section{Kadar SOD Serum}

Setelah hewan coba diberi perlakuan selama tiga puluh hari, dilakukan pembedahan dan pengambilan darah hewan coba melalui jantung. Dari sampel darah tersebut dilakukan pengukuran kadar SOD dengan menggunakan spektrofotometer. Rerata kadar SOD serum ditunjukkan pada Gambar 1 di bawah ini. 


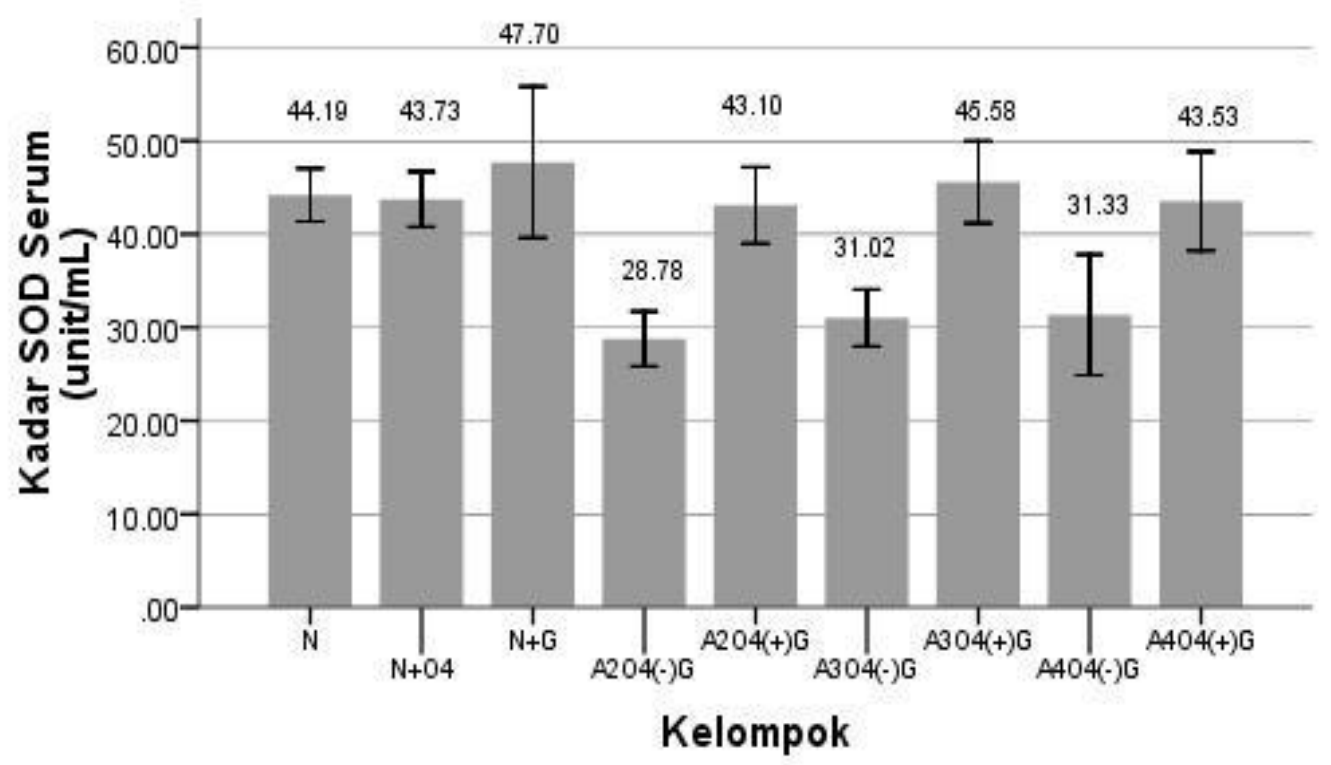

Gambar 1. Rerata kadar SOD serum antar kelompok hewan coba

Keterangan: $\mathrm{N}$ : kontrol negatif, $\mathrm{N}+\mathrm{O}_{4}$ : normal + oksigen 4 menit, $\mathrm{N}+\mathrm{G}$ : normal + ekstrak kacang tunggak, $\mathrm{A}_{2} \mathrm{O}_{4}(-) \mathrm{G}$ : Asap 2 menit + oksigen 4 menit, $\mathrm{A}_{2} \mathrm{O}_{4}(+) \mathrm{G}$ : asap 2 menit + oksigen 4 menit + ekstrak kacang tunggak, $\mathrm{A}_{3} \mathrm{O}_{4}(-) \mathrm{G}$ : asap 3 menit + oksigen 4 menit, $\mathrm{A}_{3} \mathrm{O}_{4}(+) \mathrm{G}$ : asap 3 menit + oksigen 4 menit + ekstrak kacang tunggak, $\mathrm{A}_{4} \mathrm{O}_{4}(-) \mathrm{G}$ : asap 4 menit + oksigen 4 menit, $\mathrm{A}_{4} \mathrm{O}_{4}(+) \mathrm{G}$ : asap 4 menit + oksigen 4 menit + ekstrak kacang tunggak.

\section{Uji Shapiro Wilk}

Untuk mengetahui distribusi data, dilakukan uji normalitas menggunakan Shapiro-Wilk test. Kadar SOD serum memiliki $p>0.05$ pada semua kelompok menunjukkan bahwa distribusi data normal.

\section{Uji Homogenitas}

Dari uji homogenitas, kadar SOD serum memiliki nilai $p=0,517$ yang menunjukkan bahwa data memiliki varians homogen $(p>$ 0,05).

\section{Uji One-way ANOVA}

Analisis dengan menggunakan uji one way ANOVA bertujuan untuk menilai perbedaan kadar SOD serum antar kelompok dengan cara melihat nilai signifikansi ( $p$ ). Dari hasil pengujian didapatkan bahwa nilai $p=0,009$ dan berdasarkan hasil tersebut maka $p<0,05$ sehingga dapat disimpulkan bahwa terdapat perbedaan yang bermakna pada kadar SOD serum antar dua kelompok yang berbeda.

\section{Uji Post Hoc LSD}

Selanjutnya menggunakan analisis posthoc untuk mengetahui kelompok mana yang memiliki perbedaan secara bermakna. Pada uji post-hoc suatu data dikatakan berbeda secara bermakna apabila nilai signifikansi $p<0,05$ serta interval kepercayaan 95\%. Hasil komparasi ditunjukkan pada Tabel 2. Kelompok N terdapat perbedaan yang signifikan dibandingkan dengan kelompok A2O4(-) G ( $p$ $=0,011)$, kelompok A3O4(-)G ( $p=0,027)$, dan kelompok A4O4(-)G ( $p=0,031)$. Kelompok $\mathrm{A}_{2} \mathrm{O}_{4}(+) \mathrm{G}$ terdapat peningkatan kadar SOD serum yang signifikan dibandingkan dengan kelompok $\mathrm{A}_{2} \mathrm{O}_{4}(-) \mathrm{G}$ ( $\mathrm{p}$ $=0,017)$. Kelompok $\mathrm{A}_{3} \mathrm{O}_{4}(+) \mathrm{G}$ terdapat peningkatan kadar SOD serum yang signifikan dibandingkan dengan kelompok $\mathrm{A}_{3} \mathrm{O}_{4}(-) \mathrm{G}(\mathrm{p}=0,016)$. Kelompok $\mathrm{A}_{4} \mathrm{O}_{4}(+) \mathrm{G}$ terdapat peningkatan kadar SOD serum yang signifikan dibandingkan dengan kelompok $\mathrm{A}_{4} \mathrm{O}_{4}(-) \mathrm{G} \quad(\mathrm{p}=0,040)$. Pada kelompok $\mathrm{A}_{2} \mathrm{O}_{4}(-) \mathrm{G}$ tidak dijumpai perbedaan kadar SOD serum yang signifikan 
dibandingkan dengan kelompok $\mathrm{A}_{3} \mathrm{O}_{4}(-) \mathrm{G} \quad$ dan $\mathrm{A}_{4} \mathrm{O}_{4}(-) \mathrm{G}(\mathrm{p}=0,694 ; p=0,655)$.

Tabel 2. Hasil Uji Post Hoc LSD

$\begin{array}{llllllllll}\begin{array}{l}\text { Kelompok } \\ \text { Perlakuan }\end{array} & \text { P1 } & \text { P2 } & \text { P3 } & \text { P4 } & \text { P5 } & \text { P6 } & \text { P7 } & \text { P8 } & \text { P9 }\end{array}$

\begin{tabular}{cccccccccc}
\hline P1 & - & $0,936^{* *}$ & $0,539^{* *}$ & $0,011^{*}$ & $0,849^{* *}$ & $0,027^{*}$ & $0,808^{* *}$ & $0,031^{*}$ & $0,908^{* *}$ \\
\hline P2 & $0,936^{* *}$ & - & $0,488^{* *}$ & $0,013^{*}$ & $0,912^{* *}$ & $0,033^{*}$ & $0,746^{* *}$ & $0,037^{*}$ & $0,972^{* *}$ \\
\hline P3 & $0,539^{* *}$ & $0,488^{* *}$ & - & $0,002^{*}$ & $0,423^{* *}$ & $0,006^{*}$ & $0,710^{* *}$ & $0,007^{*}$ & $0,467^{* *}$ \\
\hline P4 & $0,011^{*}$ & $0,013^{*}$ & $0,002^{*}$ & - & $0,017^{*}$ & $0,694^{* *}$ & $0,006^{*}$ & $0,655^{* *}$ & $0,014^{*}$ \\
\hline P5 & $0,849^{* *}$ & $0,912^{* *}$ & $0,423^{* *}$ & $0,017^{*}$ & - & $0,042^{*}$ & $0,665^{* *}$ & $0,047^{*}$ & $0,940^{* *}$ \\
\hline P6 & $0,027^{*}$ & $0,033^{*}$ & $0,006^{*}$ & $0,694^{* *}$ & $0,042^{*}$ & - & $0,016^{*}$ & $0,957^{* *}$ & $0,035^{*}$ \\
\hline P7 & $0,808^{* *}$ & $0,746^{* *}$ & $0,710^{* *}$ & $0,006^{*}$ & $0,665^{* *}$ & $0,016^{*}$ & - & $0,018^{*}$ & $0,720^{* *}$ \\
\hline P8 & $0,031^{*}$ & $0,037^{*}$ & $0,007^{*}$ & $0,655^{* *}$ & $0,047^{*}$ & $0,957^{* *}$ & $0,018^{*}$ & - & $0,040^{*}$ \\
\hline P9 & $0,908^{* *}$ & $0,972^{* *}$ & $0,467^{* *}$ & $0,014^{*}$ & $0,940^{* *}$ & $0,035^{*}$ & $0,720^{* *}$ & $0,040^{*}$ & -
\end{tabular}

Keterangan:

* terdapat perbedaan yang bermakna

** tidak terdapat perbedaan yang bermakna

$P 1=N, P 2=N+04, P 3=N+G, P 4=A 2 O 4(-) G P 5=A 2 O 4(+) G, P 6=A 304(-) G, P 7=A 304(+) G$,

$P 8=A 404(-) G, P 9=A 404(+) G$

\section{Pembahasan}

Penelitian ini bertujuan untuk mengetahui pengaruh genistein pada ekstrak kacang tunggak (Vigna unguiculata) terhadap kadar SOD serum hewan coba yang dipapar asap mesin berbahan bakar bensin. Hasil penghitungan kadar SOD serum menunjukkan bahwa rerata kadar SOD serum kelompok kontrol negatif yaitu $44,19 \pm 4,74$, lebih tinggi dibandingkan dengan kelompok $\mathrm{A}_{2} \mathrm{O}_{4}(-) \mathrm{G}$ yaitu $28,78 \pm 4,89)$ yang dipapar asap dua menit tanpa ekstrak kacang tunggak. Pada kelompok $\mathrm{A}_{3} \mathrm{O}_{4}(-) \mathrm{G}$ sebesar $31,02 \pm 5,10$ yang dipapar asap tiga menit tanpa ekstrak kacang tunggak, dan kelompok $\mathrm{A}_{4} \mathrm{O}_{4}(-) \mathrm{G}$ yaitu $31,33 \pm 10,7$. Dari analisis statistik post hoc $L S D$ didapatkan nilai signifikansi sebesar $p=0,011, p=0,027, p=0,031$ antara kelompok kontrol negatif dengan kelompok yang dipapar asap dengan variasi waktu yang berbeda.

Pembakaran yang tidak sempurna dari mesin diesel menghasilkan bermacammacam gas dan partikel yang padat maupun cair. Dibandingkan dengan mesin berbahan bakar bensin, mesin diesel menghasilkan lebih sedikit karbon monoksida, tetapi menghasilkan jauh lebih banyak nitrogen oksida, aldehida, dan yang paling penting partikel jelaga submikron yang dapat merugikan kesehatan. ${ }^{9}$ Partikel dalam asap kendaraan atau yang disebut sebagai diesel exhaust particulate (DEP) terdiri dari fine dan ultrafine, yaitu fraksi particulate matter (PM) dengan diameter $<2,5$ dan $<0,1 \mu \mathrm{m}$. DEP yang terinhalasi akan masuk dan terdeposit dengan mudah di saluran nafas dimana partikel-partikel yang berukuran sangat kecil ini memicu reaksi inflamasi dari sel target, yaitu makrofag, sel endothel, sel epitel, dan sitokin proinflamasi lain. Telah diketahui 
bahwa DEP mengandung metal transisi dan komponen organik siklus redoks pada permukaan partikel yang merupakan pemicu produksi ROS pada sel di berbagai tempat. ${ }^{4}$

Terdapat perbedaan yang signifikan antara kelompok $\mathrm{A}_{2} \mathrm{O}_{4}(-) \mathrm{G}$ dengan kelompok $\mathrm{A}_{3} \mathrm{O}_{4}(-) \mathrm{G}(\mathrm{p}=0,694)$ dan $\mathrm{A}_{4} \mathrm{O}_{4}(-) \mathrm{G}(\mathrm{p}=$ $0,655)$. Dapat disimpulkan bahwa perbedaan lama paparan tidak berpengaruh terhadap kadar SOD serum tikus. Hal ini mungkin dipengaruhi oleh beberapa faktor, antara lain perbedaan durasi pengasapan yang tidak terlalu lama. Terdapat peningkatan rerata kadar SOD serum pada kelompok yang dipapar asap tanpa ekstrak kacang tunggak. Rerata kadar SOD serum kelompok $\mathrm{A}_{2} \mathrm{O}_{4}$ ()G $(28,78 \pm 4,89)$ lebih rendah dibandingkan dengan kelompok $\mathrm{A}_{3} \mathrm{O}_{4}(-)(31,02 \pm 5,10)$ dan kelompok $\mathrm{A}_{4} \mathrm{O}_{4}(-) \mathrm{G}(31,33 \pm 10,7)$. Semakin lama pemaparan asap, kadar SOD serum semakin meningkat. Diduga paparan asap mesin berbahan bakar bensin menyebabkan peningkatan radikal superoksida dalam serum, namun belum sampai pada taraf stres oksidatif. Berdasarkan hipotesis tingkatan stres oksidatif, tingkatan stres oksidatif paling bawah dikaitkan dengan induksi antioksidan dan enzim pendetoksifikasi. ${ }^{10}$

Rerata kadar SOD serum pada kelompok yang dipapar asap dua menit tanpa ekstrak kacang tunggak $\mathrm{A}_{2} \mathrm{O}_{4}(-) \mathrm{G}$ $(28,78 \pm 4,89)$ lebih rendah dibandingkan dengan kelompok yang dipapar asap dua menit disertai ekstrak kacang tunggak $\mathrm{A}_{2} \mathrm{O}_{4}(+) \mathrm{G}(43,10 \pm 6,82)$. Berdasarkan hasil analisis statistik Post Hoc LSD, terdapat perbedaan signifikan antara kelompok $\mathrm{A}_{2} \mathrm{O}_{4}(-$ )$G$ dengan kelompok $\mathrm{A}_{2} \mathrm{O}_{4}(+) \mathrm{G}(\mathrm{p}=0,017)$. Rerata kadar SOD serum kelompok yang dipapar asap tiga menit tanpa ekstrak kacang tunggak $\mathrm{A}_{3} \mathrm{O}_{4}(-) \mathrm{G}(31,02 \pm 5,10)$ lebih rendah dibandingkan dengan kelompok yang dipapar asap tiga menit disertai ekstrak kacang tunggak $\mathrm{A}_{3} \mathrm{O}_{4}(+) \mathrm{G} \quad(45,58 \pm 7,35)$. Berdasarkan hasil analisis statistik post hoc $L S D$, terdapat perbedaan signifikan antara kelompok $\mathrm{A}_{3} \mathrm{O}_{4}(-) \mathrm{G}$ dengan kelompok $\mathrm{A}_{3} \mathrm{O}_{4}(+) \mathrm{G}(\mathrm{p}=0,016)$. Rerata kadar SOD serum kelompok yang dipapar asap empat menit tanpa ekstrak kacang tunggak $\mathrm{A}_{4} \mathrm{O}_{4}(-$ )G $(31,33 \pm 10,77)$ lebih rendah dibandingkan dengan kelompok yang dipapar asap disertai ekstrak kacang tunggak $\mathrm{A}_{4} \mathrm{O}_{4}(+) \mathrm{G}$ $(43,53 \pm 11,30)$. Berdasarkan hasil analisis statistik post hoc $L S D$, terdapat perbedaan signifikan antara kelompok $\mathrm{A}_{4} \mathrm{O}_{4}(-) \mathrm{G}$ dengan kelompok $\mathrm{A}_{4} \mathrm{O}_{4}(+) \mathrm{G}(\mathrm{p}=0,040)$.

Hasil penghitungan rerata kadar SOD serum menunjukkan bahwa tidak terdapat perbedaan yang signifikan $(p>0,05)$ antara kelompok kontrol negatif dengan kelompok yang dipapar asap disertai dengan ekstrak kacang tunggak dengan durasi pengasapan masing-masing kelompok selama dua menit $(p=0,849)$, tiga menit $(p=0,808)$, dan empat menit $(p=0,908)$. Dapat diartikan bahwa rerata kadar SOD serum pada kelompok yang dipapar asap disertai dengan ekstrak kacang tunggak mendekati rerata kadar SOD serum kelompok kontrol negatif.

Genistein merupakan suatu derivat isoflavon yang memiliki efek antioksidan penting antara lain mempengaruhi ekspresi gen. Genistein yang banyak terkandung dalam diet protein kedelai memiliki banyak manfaat kardioprotektif, diantaranya dapat menurunkan kolesterol LDL, inhibisi sitokin proinflamatori, menginduksi protein untuk adhesi sel, mencegah oksidasi partikel LDL, serta inhibisi agregasi platelet dan memperbaiki reaktivitas vaskular. ${ }^{11}$ Mekanisme antioksidan genistein meliputi antara lain, supresi pembentukan ROS dengan cara inhibisi enzim atau mengkelasi trace element yang terlibat dalam proses pembentukan radikal bebas, sebagai scavenger ROS, dan up-regulation enzim antioksidan. ${ }^{12}$ Genistein juga telah diketahui secara signifikan meningkatkan aktivitas enzim antioksidan seperti SOD, katalase (CAT), dan glutathione peroxidase (GPx).

Dengan demikian dapat disimpulkan bahwa pemberian ekstrak kacang tunggak meningkatkan kadar SOD serum pada Rattus norvegicus strain Wistar yang dipapar asap mesin berbahan bakar bensin. Hal ini didukung oleh penelitian sebelumnya, dimana tikus yang diberi diet rendah protein kedelai terdapat penurunan ekspresi gen 
antioksidan dan kadar eNOS disertai dengan gangguan reaktivitas vaskular dan peningkatan tekanan darah pada tikus. Selanjutnya tikus diberikan diet kaya protein kedelai dan menunjukkan peningkatan eNOS dan enzim antioksidan dua sampai tiga kali serta perbaikan relaksasi endothel dan penurunan tekanan darah. ${ }^{13}$

\section{Kesimpulan}

Penelitian ini menyimpulkan bahwa paparan asap mesin berbahan bakar bensin dapat menurunkan kadar SOD serum tikus Wistar dan tidak dipengaruhi oleh lama waktu paparan (2 menit, 3 menit, dan 4 menit). Serta pemberian ekstrak kacang tunggak (Vigna unguiculata) dapat meningkatkan kadar SOD serum tikus Wistar yang dipapar asap mesin berbahan bakar bensin secara signifikan.

\section{Saran}

1. Perlu dilakukan penelitian lebih lanjut dengan variasi waktu paparan asap dengan perbandingan durasi yang lebih lama disertai dengan modifikasi alat pengasapan dengan pengatur tekanan yang stabil dan variasi model pengasapan agar tikus tahan terpapar dalam waktu yang cukup lama.

2. Perlu dilakukan penelitian lebih lanjut untuk mengetahui mekanisme molekular kacang tunggak dalam menghambat penurunan kadar SOD serum tikus Wistar yang dipapar asap mesin berbahan bakar bensin.

3. Perlu dilakukan penelitian lebih lanjut mengenai berbagai jenis ekstrak kacang tunggak yang efektif terhadap penghambatan penurunan kadar SOD serum tikus Wistar yang dipapar asap mesin berbahan bakar bensin serta meningkatkan penggunaannya di masyarakat untuk mencegah dampak penyakit akibat polusi.

\section{Daftar Pustaka}

1. Arianto A. Kendaraan Bermotor di Indonesia Terbanyak di ASEAN. (Online). 2011. .Http://Www.Tempo.Co/Read/News/20 11/08/19/124352572/KendaraanBermotor-Di-Indonesia-Terbanyak-DiASEAN. Diakses 15 Januari 2012, pukul 14.41 WIB.

2. Sagai M, Hiroki S, Takamichi I, Masahiko K, and Yoki Mori. Biological Effects of Diesel Exhaust Particles I In Vitro Production of Superoxide and In Vivo Toxicity in Mouse. Free Radical Biology and Medicine. 1993; 4(1):3747.

3. Cozzi E, Surovi H, Howard WS, Wayne EC, Robert BD, Robert ML, Christopher JW, and Michael R Van Scott. Ultrafine Particulate Matter Exposure Augments Ischemia-Reperfusion Injury in Mice. Am J Physiol Heart Circ Physiol. 2006; 291(2):H894-H903.

4. Araujo JA, Berenice $B$, Michael $K$, Xuping W, Brian JB, Ke WG, Mohamad $\mathrm{N}$, et al. Ambient Particulate Pollutants in the Ultrafine Range Promote Early Atherosclerosis and Systemic Oxidative Stress. Circulation Research. 2008; 102(5):589-596.

5. Scandalios JG. Oxidative Stress: Molecular Perception and Transduction of Signals Triggering Antioxidant Gene Defenses. Braz J Med Biol Res. 2005; 38(7):995-1014.

6. Davies, Kelvin JA. Oxidative Stress, Antioxidant Defenses, and Damage Removal, Repair, and Replacement Systems. IUBMB life. 2000; 50(45):279-289.

7. Vedavanam K, Srijayanta S, O'Reilly J, Raman A, Wiseman H. Antioxidant Action and Potential Antidiabetic Properties of Anisoflavonoid-Containing Soybean Phytochemical Extract (SPE). Phytothes Res. 1999; 13:601-608. 
8. Pawiroharsono S. Prospek dan Manfaat Isoflavon untuk Kesehatan. (Online). 2001. http://www.tempo.co.id/medika/arsip/04 2001/pus-2.htm.

9. Sydbom A, Blomberg A, Parnia S, Stenfors N, Sandström T, and Dahlen SE. Health Effects of Diesel Exhaust Emissions. European Respiratory Journal. 2001; 17(4): 733-746.

10. Nel A, Tian X, Lutz $M$, and Ning Li. Toxic Potential of Materials at the Nanolevel. Science. 2006; 311(5761):622-627.

11. Rimbach $G$, Saadatmandi $C B$, Jan $F$, Dagmar F, Uwe W, Hannelore D,
Wendy L. Hall, and Peter DW. Dietary Isoflavones in the Prevention of Cardiovascular Disease-A Molecular Perspective. Food and Chemical Toxicology. 2008; 46(4):1308-1319.

12. Pietta PG. Flavonoids as Antioxidants. Journal of natural products. 2000; 63(7):1035-1042.

13. Mahn K, Consuelo B, Greg AK, Paul T, Imran YK, David $S$, Lucilla $P$ et al. Dietary Soy Isoflavone Induced Increases in Antioxidant and eNOS Gene Expression Lead to Improved Endothelial Function and Reduced Blood Pressure In Vivo. The FASEB journal. 2005; 19(12):1755-1757. 